\title{
Oligometastatic non-small cell lung cancer (NSCLC)
}

Citation for published version (APA):

Giaj-Levra, N., Levra, M. G., Berghmans, T., Novello, S., Hendriks, L. E., Levy, A., Besse, B., \& Dingemans, A-M. C. (2020). Oligometastatic non-small cell lung cancer (NSCLC): Does number of metastasis matter? Lung Cancer, 139, 216-218. https://doi.org/10.1016/j.lungcan.2019.11.005

Document status and date:

Published: 01/01/2020

DOI:

10.1016/j.lungcan.2019.11.005

Document Version:

Publisher's PDF, also known as Version of record

Document license:

Taverne

Please check the document version of this publication:

- A submitted manuscript is the version of the article upon submission and before peer-review. There can be important differences between the submitted version and the official published version of record.

People interested in the research are advised to contact the author for the final version of the publication, or visit the DOI to the publisher's website.

- The final author version and the galley proof are versions of the publication after peer review.

- The final published version features the final layout of the paper including the volume, issue and page numbers.

Link to publication

\footnotetext{
General rights rights.

- You may freely distribute the URL identifying the publication in the public portal. please follow below link for the End User Agreement:

www.umlib.nl/taverne-license

Take down policy

If you believe that this document breaches copyright please contact us at:

repository@maastrichtuniversity.nl

providing details and we will investigate your claim.
}

Copyright and moral rights for the publications made accessible in the public portal are retained by the authors and/or other copyright owners and it is a condition of accessing publications that users recognise and abide by the legal requirements associated with these

- Users may download and print one copy of any publication from the public portal for the purpose of private study or research.

- You may not further distribute the material or use it for any profit-making activity or commercial gain

If the publication is distributed under the terms of Article $25 \mathrm{fa}$ of the Dutch Copyright Act, indicated by the "Taverne" license above, 
Editorial

\section{Oligometastatic non-small cell lung cancer (NSCLC): Does number of metastasis matter?}

Synchronous oligometastatic (sOM) status is perceived as a distinct disease from polymetastatic presentation, with a potential higher overall survival (OS) probability when treated with local radical treatment (LRT).

Recently, the long-term outcomes of the practice changing phase II randomized trial on sOM non-small cell lung cancer (NSCLC) were published [1]. Forty-nine patients with up to 3 metastases (primary tumor excluded) after first line systemic therapy were randomized to either LRT (i.e. radiotherapy or surgery) to all disease sites or maintenance systemic therapy (MT)/observation (O). This trial demonstrated that LRT improved OS, median 41.2 months (95 \% CI, 18.9 months to not reached) in LRT and 17.0 months (95 \% CI, 10.1-39.8 months) in MT/O (p = 0.017). These results supported the integration of LRT in SOM-NSCLC and its implementation in daily clinical practice.

However, despite some consensus about sOM status, a uniform definition does not exist as reported in a systematic review performed by the European Organization for the Research and Treatment of Cancer (EORTC)

Table 1

Article included in the systematic review [2] and current literature [3,4].

\begin{tabular}{|c|c|c|c|c|c|}
\hline Articles & $\begin{array}{l}\text { Number of } \\
\text { patients }\end{array}$ & $\begin{array}{l}\text { Maximal number } \\
\text { metastases defined }\end{array}$ & $\begin{array}{l}\text { Maximal number of } \\
\text { metastases treated }\end{array}$ & $\begin{array}{l}\text { Patients with } \leq 2 \text { metastases treated } \\
(\%)\end{array}$ & $\begin{array}{l}\text { Patients with } \geq 3 \text { metastases included } \\
\text { (\%) }\end{array}$ \\
\hline Downey R. 2002 & 23 & 1 & 1 & $100 \%$ & $0 \%$ \\
\hline Khan A. 2006 & 23 & 2 & 2 & $100 \%$ & $0 \%$ \\
\hline Inoue St et al. 2010 & 25 & 5 & 5 & N.A. & N.A. \\
\hline Cheruvu P. 2011 & 38 & 8 & 8 & N.A & N.A \\
\hline Collaud S. 2012 & 29 & 1 & 1 & $100 \%$ & $0 \%$ \\
\hline Congedo M. 2012 & 53 & 2 & 2 & $100 \%$ & $0 \%$ \\
\hline De Ruysscher D. 2012 & 40 & 5 & 3 & $97.4 \%$ & $2.6 \%$ \\
\hline Lopez Guerra J. 2012 & 78 & 4 & 4 & $91 \%$ & $9 \%$ \\
\hline Griffioen G. 2013 & 61 & 3 & 3 & $96.7 \%$ & $3.3 \%$ \\
\hline Nieder C.S. 2014 & 23 & 3 & 2 & $100 \%$ & $0 \%$ \\
\hline Parikh R. 2014 & 186 & 5 & 5 & $74 \%$ & $26 \%$ \\
\hline Sheu T. 2014 & 90 & 3 & 3 & $88 \%$ & $12 \%$ \\
\hline Plones T. 2015 & 56 & 5 & 4 & $99 \%$ & $1 \%$ \\
\hline Su Ss. 2015 & 198 & 3 & 3 & $56 \% *$ & $44 \% *$ \\
\hline Xanthopoulos E. et al. 2015 & 25 & 4 & 4 & $84 \%$ & $16 \%$ \\
\hline Fleckenstein J. 2016 & 39 & 5 & 5 & $90 \%$ & $10 \%$ \\
\hline Johnson K. 2016 & 37 & 5 & N.A. & N.A. & N.A. \\
\hline Sakai Ks.2016 & 18 & 5 & N.A. & N.A. & N.A. \\
\hline Su Ss. 2016 & 91 & 4 & N.A. & N.A. & N.A. \\
\hline Iyengar P. 2017 & 29 & 5 & 3 & $93 \% * *$ & $7 \%$ \\
\hline Gomez D. 2019 & 49 & 3 & 3 & $98 \%$ & $2 \%$ \\
\hline $\begin{array}{l}\text { Bauml JM. } \\
2019 \text { [3] }\end{array}$ & 51 & 4 & 4 & $94 \%$ & $6 \%$ \\
\hline $\begin{array}{l}\text { Arrieta O. } \\
\qquad 2019 \text { [4] }\end{array}$ & 37 & 5 & N.A. & $65 \%$ & $35 \%$ \\
\hline
\end{tabular}

*56 \% with single metastasis, $44 \% \geq 2$ metastases; ** 14 patients received a LCT (randomized trial); N.A.: not available. 
lung cancer group (LCG) [2]. Specifically, EORTC (in collaboration with European Society for radiotherapy and oncology - ESTRO) is promoting an ongoing trial ( $\mathrm{E}^{2}$-RADIatE-OligoCare) including SOM and oligorecurrent patients with the primary outcome to identify patient, tumour (NSCLC, breast, prostate and colon-rectal cancers) staging and treatment characteristics impacting in OS.

About the systematic review, the aim was to provide an overview of sOM-NSCLC definition from reported series and trials [2]. The maximum number of metastases ranged from 1 to 8 in 21 selected articles [2]. Additionally, the definition of sOM-NSCLC in prospective clinical trials is also heterogeneous and vary between 1 and 6 [2-5]. Further, $74-100 \%$ of 1211 included in the systematic review patients had $\leq 2$ metastatic sites. Furthermore, total numbers of metastases detected and treated were not described in 5 (24\%) studies, restricting clinical interpretation on the role of LRT (Table 1). In the recent randomized Gomez et al. trial, inclusion criteria allowed up to three metastases but the majority of patients (65\%) had only $0-1$ [1].

Not surprisingly, the field is moving towards allowing higher number of metastases in clinical trials, as technically LRT is feasible for an increasing number of sites.

Recently, the EORTC-LCG published a consensus about the maximal number of metastases allowed to define sOM-NSCLC. Authors evaluated sOM-NSCLC definitions in daily clinical practice in Europe, by a survey and discussion of ten real life cases $[7,8]$. In the survey, the maximum number of metastases considered as SOM-NSCLC was again variable and $42 \%$ of responders identified 3 as the correct definition [7]. Then analyzing real life cases, sOM-NSCLC was conservative and linked to radical intent of treatment. Members of the consensus meeting concluded that the maximum number of metastases is depending on the possibility to offer a LRT strategy [6].

Finally, based on the systematic review, most studies did not specify the local nodal status (N-status), although it is known that advanced $\mathrm{N}$ status is associated with lower OS [7]. In the Gomez et al. trial, besides LRT, only number of metastases and presence of a driver alteration were associated with improved OS [1]. N2/N3 disease was non-significant in OS, probably due to the limited number of enrolled patients. As even, in Gomez et al. not all patients benefited from LRT and a correct selection is advocated. The ongoing SARON trial (NCT02417662) could provide answers, as patients will be stratified according to mediastinal N-status (N 0-1 vs N2-3), histology (adeno- vs non-adenocarcinoma), brain metastases (present vs absent) and number of oligometastatic sites (1 vs 2 vs 3). Other factors such as circulating tumour DNA and molecular signatures should be evaluated in future trials $[10,11]$.

In order to select sOM-NSCLC patients, accurate radiological and pathological staging (preferably including molecular characterization) is needed [9]. Therefore, as described in EORTC articles [2,5], ${ }^{18}$ FDGPET-CT, brain MRI-scan and a possible pathological proof of a metastasis are necessary. The promising data about immunotherapy and radiation combination are inspiring new sOM-NSCLC trials, investigating the association of these treatments [3]. Hence, a single definition and recommended staging work-up are crucial.

The EORTC LCG approach is based on a secure methodology, because expert team carried out the systematic review, while survey and clinical cases discussion contributed on basic scenario about sOMNSCLC treatment in Europe. Finally, a consensus meeting was held. Based on findings coming from the previous 3 steps, proposals were discussed and definitions were consensually agreed between scientific societies involved in lung cancer treatment (surgeon, pneumologist, radiation and medical oncologist) [6]. The EORTC LCG consensus definition is a good starting point for future clinical trials selecting the correct patient for the fit oncological treatment [5].

\section{Contributors}

All Authors contributed equally.

\section{Declaration of Competing Interest}

None.

\section{References}

[1] D.R. Gomez, C. Tang, J. Zhang, G.R. Blumenschein Jr, M. Hernandez, J.J. Lee, et al., Local consolidative therapy vs. maintenance therapy or observation for patients with oligometastatic non-small-cell lung cancer: long-term results of a multi-institutional, phase II, randomized study, J. Clin. Oncol. 37 (2019) 1558-1565.

[2] N. Giaj-Levra, M. Giaj-Levra, V. Durieux, S. Novello, B. Besse, B. Hasan, et al., Defining synchronous oligometastatic non-small cell lung cancer: a systematic review, J. Thorac. Oncol. (2019), https://doi.org/10.1016/j.jtho.2019.05.037 [Epub ahead of print].

[3] J.M. Bauml, R. Mick, C. Ciunci, C. Aggarwal, C. Davis, T. Evans, et al., Pembrolizumab after completion of locally ablative therapy for oligometastatic non-small cell lung Cancer: a phase 2 trial, JAMA Oncol. (2019), https://doi.org/10.1001/jamaoncol.2019. 1449 [Epub ahead of print].

[4] O. Arrieta, F. Barrón, F. Maldonado, L. Cabrera, J.F. Corona-Cruz, M. Blake, et al., Radical consolidative treatment provides a clinical benefit and long-term survival in patients with synchronous oligometastatic non-small cell lung cancer: a phase II study, Lung Cancer 130 (2019) 67-75.

[5] J. Conibear, B. Chia, Y. Ngai, A.T. Bates, N. Counsell, R. Patel, et al., Study protocol for the SARON trial: a multicentre, randomised controlled phase III trial comparing the addition of stereotactic ablative radiotherapy and radical radiotherapy with standard chemotherapy alone for oligometastatic non-small cell lung cancer, BMJ Open 8 (2018) e020690.

[6] A.C. Dingemans, L.E.L. Hendriks, T. Berghmans, A. Levy, B. Hasan, C. Faivre-Finn, et al., Definition of syncronous oligo-metastatic non-small cell lung cancer - a consensus report, J. Thorac. Oncol. (2019), https://doi.org/10.1016/j.jtho.2019.07.025 [Epub ahead of print]

[7] A. Levy, L.E.L. Hendriks, T. Berghmans, C. Faivre-Finn, M. GiajLevra, N. GiajLevra, et al., EORTC Lung Cancer group survey on the definition of NSCLC synchronous oligometastatic disease, Eur. J. Cancer 122 (2019) 109-114.

[8] L.E.L. Hendriks, C. Dooms, T. Berghmans, S. Novello, A. Levy, D. De Ruysscher, et al., Defining oligometastatic non-small cell lung cancer: a simulated multidisciplinary expert opinion, Eur. J. Cancer 23 (123) (2019) 28-35.

[9] N.M. deSouza, Y. Liu, A. Chiti, D. Oprea-Lager, G. Gebhart, B.E. Van Beers, et al., Strategies and technical challenges for imaging oligometastatic disease: 
recommendations from the European Organisation for Research and Treatment of Cancer imaging group, Eur. J. Cancer 91 (2018) 153-163.

[10] A.B. Ashworth, S. Senan, D. A. Palma, M. Riquet, Y.C. Ahn, U. Ricardi, et al., An individual patient data metaanalysis of outcomes and prognostic factors after treatment of oligometastatic non-small-cell lung cancer, Clin. Lung Cancer 15 (2014) 346-355.

[11] A. Uppal, S.C. Wightman, S. Mallon, G. Oshima, S.P. Pitroda, Q. Zhang, et al., 14q32encoded microRNAs mediate an oligometastatic phenotype, Oncotarget 6 (2015) 3540-3552.

Niccolò Giaj-Levra ${ }^{\mathrm{a}, \mathrm{b}, \ldots}$

a Department of Advanced Radiation Oncology, IRCCS Sacro Cuore Don Calabria Hospital, Negrar di Valpolicella, Italy

${ }^{\mathrm{b}}$ Young Investigators European Organization for Research and Treatment of Cancer Lung Cancer Group, Brussels, Belgium E-mail address: niccolo.giajlevra@sacrocuore.it.

Matteo Giaj Levra ${ }^{\mathrm{a}, \mathrm{b}}$

${ }^{a}$ Young Investigators European Organization for Research and Treatment of Cancer Lung Cancer Group, Brussels, Belgium

${ }^{\mathrm{b}}$ Respiratory Oncology Unit, Department of Thoracic and Vascular Disease, CHU Grenoble Alpes, Grenoble, France

Thierry Berghmans

Department of Intensive Care and Oncological Emergencies and Thoracic Oncology, Institut Jules Bordet, Université Libre de Bruxelles, Brussels,

Belgium

Silvia Novello

Oncology Department, University of Turin, AOU San Luigi, Orbassano, Italy
Lizza E. Hendriks ${ }^{\mathrm{a}, \mathrm{b}}$

${ }^{a}$ Young Investigators European Organization for Research and Treatment of Cancer Lung Cancer Group, Brussels, Belgium

${ }^{\mathrm{b}}$ Department of Pulmonary Diseases, GROW-School for Oncology and Developmental Biology, Maastricht University Medical Center, Maastricht, the Netherlands

Antonin Levy ${ }^{\mathrm{a}, \mathrm{b}}$

${ }^{a}$ Young Investigators European Organization for Research and Treatment of Cancer Lung Cancer Group, Brussels, Belgium

${ }^{\mathrm{b}}$ Department of Radiation Oncology, Gustave Roussy, Institut d'Oncologie Thoracique, INSERM U1030, Université Paris-Saclay, F-94805, Villejuif,

France

Benjamin Besse

Department of Cancer Medicine, Gustave Roussy, Institut d'Oncologie Thoracique, Gustave Roussy, Université Paris-Saclay, F-94805, Villejuif,

France

Anne-Marie C. Dingemans $\mathrm{s}^{\mathrm{a}, \mathrm{b}}$

${ }^{a}$ Department of Pulmonary Diseases, GROW-School for Oncology and Developmental Biology, Maastricht University Medical Center, Maastricht, the Netherlands

${ }^{\mathrm{b}}$ Department of Pulmonary Diseases, Erasmus Medical Center, Rotterdam, the Netherlands

${ }^{*}$ Corresponding author at: Department of Advanced Radiation Oncology, IRCCS Sacro Cuore Don Calabria Hospital, Negrar di Valpolicella, Italy. 